\title{
Relation of Meteorological Factors with Growth, Yield and Value of Flue-cured Tobacco in Young Seedlings Transplanting Modes Under to Above Film
}

\author{
Folin $\mathrm{Li}^{1}$, Ke Ren ${ }^{1}$, Xingwei $\mathrm{Ji}^{2}{ }^{\text {, }}$, Yingcheng $\mathrm{Guo}^{3}$, Yidan Zhang ${ }^{3}$, Zhiming $\mathrm{Hu}^{2}$, Chenren Ouyang ${ }^{1}$ \\ ${ }^{1}$ College of Tobacco Science, Yunnan Agricultural University, Kunming, China \\ ${ }^{2}$ Honghe Branch Company of Yunnan Tobacco Company, Mile, China \\ ${ }^{3}$ Baoshan Branch Company of Yunnan Tobacco Company, Baoshan, China
}

\section{Email address:}

fordmail@163.com (Folin Li), jxw312@126.com (Xingwei Ji)

${ }^{*}$ Corresponding author

\section{To cite this article:}

Folin Li, Ke Ren, Xingwei Ji, Yingcheng Guo, Yidan Zhang, Zhiming Hu, Chenren Ouyang. Relation of Meteorological Factors with Growth, Yield and Value of Flue-cured Tobacco in Young Seedlings Transplanting Modes Under to Above Film. American Journal of Agriculture and Forestry. Vol. 7, No. 3, 2019, pp. 95-105. doi: 10.11648/j.ajaf.20190703.12

Received: March 12, 2019; Accepted: May 6, 2019; Published: June 12, 2019

\begin{abstract}
To explore the transplanted pattern meteorological foundation, a set of 10 field experiments that including the pattern of 5 leaves age young seedling transplant modes under plastic mulching (YSTUPM) and 12 leaves age conventional pattern above plastic mulching (CPAPM) was conducted to analyze the relation of meteorological factors with the growth period, economic characteristics. The results showed that (1) There were the positively correlations, which day after transplanted (DAT) to root spreading stage with product of accumulation value of air temperature and sunshine hours $\left(r=0.727^{* *}\right)$ and accumulation value of sunshine hours in the fast growing period $\left(r=0.710^{* *}\right)$, DAT with daily mean of sunshine hours $\left(r=0.673^{*}\right)$ and accumulation value of sunshine hours in the maturity stage $\left(r=0.675^{*}\right)$; While the negatively correlations, which DAT with daily mean of rainfall $\left(r=-0.723^{* *}\right)$, product by daily mean of air temperature and sunshine hours and rainfall $(r=-0.764 * *)$, accumulation value of air temperature in the fast growing period $(r=-0.693 *)$. (2) There were the close correlations between the economic characteristics with the meteorological factors, Which in the whole field growing duration, which yield with daily mean of air temperature $\left(r=0.773^{* *}\right)$, accumulation values of air temperature $\left(r=0.880^{* *}\right)$, product by daily mean of air temperature and sunshine hours $\left(r=0.888^{* *}\right)$; value with product by daily mean of air temperature and sunshine hours $\left(r=0.825^{* *}\right)$, product by accumulation value of air temperature and sunshine hours $\left(r=0.707^{*}\right)$, accumulation values of air temperature $\left(r=0.880^{* *}\right)$. while price were negatively correlations with daily mean of air temperature $\left(r=-0.926^{* *}\right)$, accumulation values of air temperature $\left(r=-0.745^{* *}\right)$, product by daily mean of air temperature and sunshine hours and rainfall $\left(r=-0.590^{*}\right)$, product by accumulation value of air temperature and sunshine hours and rainfall $(r$ $\left.=-0.666^{*}\right)$; the middle leaf with product by daily mean of air temperature and sunshine hours and rainfall $\left(r=-0.601^{*}\right)$. In the fast growing period, super leaf rate with product by accumulation value of air temperature and sunshine hours $\left(r=0.629^{*}\right)$, while the middle leaf rate with product by accumulation value of air temperature and sunshine hours $\left(r=-0.653^{*}\right)$.
\end{abstract}

Keywords: Flue-cured Tobacco, 5 Leaves Age Seedlings, Transplanted Under Film, Growth Period, Yield and Value, Meteorological Factors

\section{Introduction}

Young Seedling Transplant under Plastic Mulching (YSTUPM), relative to Conventional Pattern above Plastic Mulching (CPAPM), it refers to the cultivation method of transplanting with 5 leaves seedling in $35 \mathrm{~d}$ after sowing, while conventional pattern above plastic mulching with 12 leaves seedling in $60 \mathrm{~d}$ after sowing, the whole seedling is covered under the film, and the seedling grows about $15-20 \mathrm{~d}$ under the film, then to break the film and pull the plant out of the film. YSTUPM can make full use of light, temperature, gas, water, fertilizer, soil and other natural potential and the 
effect of plastic film mulching, help to drought resistance and water saving, adapt floating seedling in advance to the soil environment, and reduce the cut when seedling leaf brings the risk of infection diseases, decrease the cost of seedling, shorten seedling period, make the reach field production period, to avoid the peak period of plant diseases and insect pests to the early stage of the low temperature and drought influence on transplanting, promote early and fast development of tobacco plant, early maturity, early recovery and improve the yield and quality of flue-cured tobacco, increase economic efficiency. YSTUPM in China began in 1990 when Xizhou Wang et al. adopted the technology of "transplanting seedlings and mulch cultivation" to solve the problems of drought and difficult transplanting during spring season in hilly hills in western Henan province [1]. In Jiamusi area of Heilongjiang province and Yan'an area of northwest area, the planting method of "Transplanted tobacco seedlings under the membrane" was tested. Later, it was quickly popularized in the low-temperature tobacco areas of northeast and northwest China during the transplanting season [2]. Early planting tobacco fields in Sanming, Fangcheng county and Dengzhou in Henan Province, Pingliang in Shanxi Province, Yinan County of Shandong, Lvliang and Taiyueshan in Shanxi Province, Mengzi city of Yunnan Honghe Prefecture, Wenshan City, Dali and Zhaotong and so on were reported on the experiment of YSTUPM [3-4]. After 2009, the drought in the tobacco area of Yunnan is more prominent [5], and tobacco mosaic virus (TMV) in the leaves are spread by the leaves of tobacco seedlings by clipping of floating seedlings [6]. So, the transplant mode has become a new practical technique for popularization and application [7].

At present, the main research contents of YSTUPM includes those output value effect [8-13], plastic film [14-15], small arch canopy structure under membrane [16], seedling tray specification [17-18], irrigation-before-transplanting [19], film uncovering mode, time and straw mulching [20-22], Seedlings ages [23], transplanting period [24-28], fertilization mode [4, 29-31], use of plant growth regulators [32], matching equipment [33], prevention of tobacco aphids [3], tobacco vein spot disease [3, 34], tobacco potato virus $Y$ (TPY) disease, tobacco cucumber virus (TCV) disease, tobacco mosaic virus disease [35-36], tobacco black shank disease [37-38], climate spot disease [19], supporting cultivation techniques and standardization procedures [4, 39-44], altitude [45], micrometeorology and so on [46]. However, there are few reports on the analysis of meteorological factors and the effect of seedling under film.

Baoshan, which belongs to the Southwest Yunnan tobacco planting area, is one of the most suitable areas for the production of high quality tobacco. It belongs to the dominant area of Chinese tobacco production [47]. This paper tries to summarize the application of transplanting technique of transplanting seedlings in Baoshan and analyze the relationship with meteorological factors, aim to clarify the effect of seedling transplanting under the flue-cured tobacco film and discuss its meteorological basis, so as to provide reference and basis for the application and mechanism interpretation of this technology.

\section{Materials and Methods}

\subsection{Experimental Design}

A total of 10 field comparative experiments were carried out in two flue-cured tobacco production seasons from 2013 to 2014 in five counties of Baoshan by YSTUPM and CPAPM (CK). It took the randomized block designed with each treatment was repeated 3 times, the each block area was $48 \mathrm{~m}^{2}$. The plant distance was $120 \mathrm{~cm} \times 50 \mathrm{~cm}$, the tested varieties selected Yunyan 87, the seedling cultivated with 200 holes floating nursery plate by floating system. Fertilizer application, seedling digging time and other agricultural management were carried out according to "Technical Operation Rules for Water-saving Transplanting of Flue-cured Tobacco Seedlings under Plastic Film" and "Comprehensive Standard of Flue-cured Tobacco in Baoshan City" (Q/BYC 1.1 47-2011). The seedling age of YSTUPM was $35 \mathrm{~d}$ and the seedling age of CPAPM was $60 \mathrm{~d}$. The time of seeding and transplanting was determined according to the specific conditions of various locals. Two kinds of seedling transplanting methods were conducted at the same time, while the conventional seedlings were transplanted after $4 \sim 20 \mathrm{~d}$.

Table 1. Date of transplanting in the field experiments (month-day).

\begin{tabular}{llllll}
\hline Year & Treatment & Shidian & Longyang & Longling & Changning \\
\hline \multirow{2}{*}{2013} & Seedling under Mulching & $4-4$ & $4-18$ & $4-26$ & $4-10$ \\
& CPAPM (CK) & $4-16$ & $5-4$ & $4-26$ & $4-10$ \\
\multirow{2}{*}{2014} & Seedling under Mulching & $4-14$ & $4-10$ & $4-10$ & $4-25$ \\
& CK & $4-14$ & $4-25$ & $4-26$ & $4-10$ \\
\hline
\end{tabular}

The test site is Yaoguan town and Taiping town in Shidian county, Longdong village of Xinjie township in Longyang district, Lameng township and Zhenan town in Longling County, Hot Spring township and Gou Street township in Changning County, Qushi township, Jietou township in Tengchong County. In the middle fertility plots, N102 $\mathrm{kg} / \mathrm{hm}^{2}$ fertilization was applied uniformly, $\mathrm{N}: \mathrm{P}_{2} \mathrm{O}_{5}: \mathrm{K}_{2} \mathrm{O}=$
$1: 2: 3$, and fertilization was applied by base fertilizer and dressing fertilizer. The base fertilizer with high quality fertilizer $\left(\mathrm{N}: \mathrm{P}_{2} \mathrm{O}_{5}: \mathrm{K}_{2} \mathrm{O}=10: 10: 29\right)$ and $15 \%$ calcium and magnesium phosphorus fertilizer produced by Yun leaf chemical fertilizer Co., Ltd. was used, dressing fertilizer with 15-0-30 potassium fertilizer and 50\% potassium sulphate was used for three times applications. 
YSTUPM were been covered film after transplanting tobacco seedlings. The depth of the pit is $10-15 \mathrm{~cm}$ and the diameter is $45 \mathrm{~cm}$. When transplanting, the tobacco seedlings be planted in depth to avoid scalding caused by the leaves of the tobacco seedlings close to the plastic film after mulching, and the transplanted seedling should be fully watered. After covering the film, a hole can be dug on the film above the seedling to ventilate, and then gradually expand the small hole as the temperature raise. The standard of transplanting young seedlings is generally 5 leaves age, stem height $1.5-1.2 \mathrm{~cm}$, which requires short stem and flat leaf, saucer-shaped seedlings. When there was $1 \mathrm{~cm}$ from seedlings to the membrane, the seedlings were digged out in a timely manner to ensure the seedlings grow outside the membrane. The operation time is usually $15 \sim 20 \mathrm{~d}$ after transplanted.

In the mode of CPAPM, the depth of tobacco seedlings exposed was $10 \sim 15 \mathrm{~cm}$ above the film, the seedling stem height was $12 \mathrm{~cm}$ to $15 \mathrm{~cm}$, the diameter of the stem was more than $0.6 \mathrm{~cm}, 12$ leaves age. The transplanting seedling have light green without bacteria (virus), the root was great developed and the fibrous root was more, no obvious root and strong stem tenacity, not easy to break.

\subsection{Determination of Items and Methods}

According to $\mathrm{YC} / \mathrm{T} 142-2010$ investigation and measuring methods of agronomical character of tobacco, the number of days after transplant was investigated. Record transplanting time, seedling stage, rosette stage, bud stage, top-cutting time, first picking and final harvest. According to GB/T 2635-92 national standard classification of flue-cured tobacco, and the local purchase price, the economic characteristics of each treatment were calculated.

The Meteorological Bureau in Baoshan provided data of the daily meteorological elements including the actual average temperature, rainfall, relative humidity and sunshine time in the experimental year.

\subsection{Data Processing}

The comparison value and relative value were used in the transplanting modes of two kinds of tobacco seedlings and the comparison of the characters of the year. At the same time, the T-test was carried out when the characters of YSTUPM and CPAPM were compared, of which $d f=12$. When the economic indicators are statistically described, $n=10$; among them,

Comparison value $=$ the characteri stic index of the YSTUPM - the characteri stic index of the CPAPM

or

Comparison value $=$ the characteri stic index in 2014 - the characteri stic index in 2013

Relative value $=\frac{\text { the characteristic index of the YSTUPM-the characteristic index of the CPAPM }}{\text { the characteristic index of the CPAPM }} \times 100 \%$

Relative value $=\frac{\text { each } \text { characteristic index in } 2014-\text { each characteristic index in } 2013}{\text { the characteristic index in } 2013} \times 100 \%$

The characteristics of meteorological elements in the 4 9 months of the main field growth period were analyzed statistically. According to YC/T142-2010 investigation and measuring methods of agronomical character of tobacco, 3 important growth periods, such as root spreading stage, fast growing period, maturity stage, and the calculation analysis and other characteristics of the meteorological factors during the growing duration after transplantation, the relationship between meteorological factors and other traits was analyzed. The root spreading stage is from seedling stage to rosette stage, the vigorous growth stage is from rosette stage to bud stage, and the mature stage is from the first picking to the final harvest. Meteorological elements and their combination data with 6 types 40 meteorological factors were related with growth period and economic traits. The temperature, rainfall, sunshine hours and their product of two or three are comprehensively calculated. The specific values are: (1) the daily average meteorological element value (Daily Mean): from the beginning of transplant to the duration of a growing period, the daily mean values of the sunshine hours (L), rainfall (R), and air temperature (T) and other elements. (2) The accumulative value of meteorological factors during the growth period (Accumulation Values): from the beginning of transplanting to the duration of a growing period, the accumulation of the average value of factor values such as sunshine hours, rainfall and air temperature. (3) Product of daily Mean of 2 factors of which sunshine hours, rainfall, air temperature: the product of the sunshine hours, rainfall, and the daily average value of two factors from the beginning of transplanting to the duration of a growing period. (4) product of accumulation values of 2 factors of which sunshine hours, rainfall, air temperature: the product of the cumulative values of the mean values of the two factors of sunshine hours, rainfall and temperature from the beginning of transplanting to the number of days of a certain growth period. (5) Product of accumulation values of 3 factors of that includes the daily average of sunshine hours, rainfall, air temperature: the product of the sunshine hours, rainfall, air temperature and the daily average value of three factors from the beginning of transplanting to the duration of a growing period. (6) product of accumulation values of 3 factors of that includes the cumulative of sunshine hours, rainfall, air temperature: the product of the cumulative value of the average value of the 3 elements, such as sunshine hours, rainfall and air temperature, from the beginning of the transplant to the certain growth period. 
Excel 2007 software and SPSS22.0 statistical analysis software were used for analysis. Using the pearson correlation analysis calculation values of meteorological elements and their combination with growth period and economic character and its two end the correlation probability value, with significant probability value of 0.05 and 0.01 level as inclusion criteria, at the same time in the related indicators to consider when the choice between the biological significance and meteorological elements and feed-forward effect between growth period, and the comprehensive effects of economic characters. For correlation analysis, $n=10$.

\section{Results and Analysis}

\subsection{Comparison of Growth Period of Flue-cured Tobacco with Two Kinds of Transplanting Modes}

As shown in table 2, from the growth period of each stage of flue-cured tobacco in the field during the two transplanting modes, the growth period of YSTUPM were longer than the $\mathrm{CK}$, and the seedling restitution stage, the rosette stage, the flower-bud appearing stage, the topping stage, the 1th picked -cured stage, and the last picked-cured stage were 2.4, 4.2, $6.2,6.6,6.6,8.8 \mathrm{~d}$ longer respectively than CK. In terms of the whole growth period, the age of the seedling under mulching was only $35 \mathrm{~d}$, while that of the CK was $60 \mathrm{~d}$. Therefore, the whole growth period of seedling under mulching were actually shortened by $16.2 \mathrm{~d}$ compared with the CK. From the time of transplanting to the 1th picked -cured stage and the last picked-cured stage, the seedling under mulching were significantly longer than the CK; while whole growth period of the seedling under mulching were significantly shorter than that of the CK.

In general, the most significant changes in the number of days after transplanting at each stage were picked-cured stage, topping stage, rosette stage, flower-bud appearing stage, seedling restitution stage, which are the reverse order compare with reproductive process. The more the growth last, the greater the different of the growth period in two modes, but the change of the whole growth period is smaller. The order of coefficient of variation of growth periods: 1th picked-cured $(78.44 \%)>$ topping $(77.7 \%)>$ rosette $(70.23 \%)>$ flower-bud appearing $(65.91 \%)>$ seedling restitution $(63.19 \%)>$ last picked-cured $(51.7 \%)>$ whole growth period $(4.70 \%)$.

The order of variation coefficients of the growth stages of YSTUPM: seedling $(30.53 \%)>$ rosette $(15.21 \%)>$ flower-bud appearing $(10.86 \%)>$ topping $(9.96 \%)>1$ th picked-cured $(5.27 \%)>$ last picked-cured $2.13 \%>$ whole growth period $(1.87 \%)$.

The order of variation coefficients of the growth stages of CPAPM: seedling $(26.27 \%)>$ rosette $(9.87 \%)>$ flower-bud appearing $(8.55 \%)>$ topping $(7.92 \%)>$ last picked-cured $(4.44 \%)>1$ th picked - cured $(4.38 \%)>$ whole growth period $(3.71 \%)$.

Table 2. Compare of flue-cured tobacco growth period in transplanted modes.

\begin{tabular}{|c|c|c|c|c|c|c|c|c|}
\hline modes & $\begin{array}{l}\text { Statistics } \\
\text { item }\end{array}$ & Seedling restitution & rosette & $\begin{array}{l}\text { flower-bud } \\
\text { appearing }\end{array}$ & topping & 1th picked-cured & $\begin{array}{l}\text { Last } \\
\text { picked-cured }\end{array}$ & $\begin{array}{l}\text { whole growth } \\
\text { period }\end{array}$ \\
\hline \multirow{5}{*}{ YSTUPM } & Mean & 10.2 & 31.4 & 71 & 78.6 & 93 & 171.6 & 206.6 \\
\hline & SD & 3.11 & 4.77 & 7.71 & 7.83 & 4.90 & 3.65 & 3.86 \\
\hline & $\mathrm{CV}$ & 30.53 & 15.21 & 10.86 & 9.96 & 5.27 & 2.13 & 1.87 \\
\hline & Min & 6 & 26 & 64 & 68 & 88 & 167 & 202 \\
\hline & $\operatorname{Max}$ & 13 & 39 & 84 & 90 & 100 & 176 & 211 \\
\hline \multirow{4}{*}{$\begin{array}{l}\text { CPAPM } \\
(\mathrm{CK})\end{array}$} & Mean & 7.8 & 27.2 & 64.8 & 72 & 86.4 & 162.8 & 222.8 \\
\hline & $\mathrm{CV}$ & 26.27 & 9.87 & 8.55 & 7.92 & 4.38 & 4.44 & 3.71 \\
\hline & Min & 6 & 25 & 61 & 67 & 81 & 151 & 211 \\
\hline & Max & 10 & 31 & 74 & 80 & 90 & 169 & 229 \\
\hline \multirow{3}{*}{ comparison } & difference & 2.4 & 4.2 & 6.2 & 6.6 & 6.6 & 8.8 & -16.2 \\
\hline & $t$ & 1.439 & 1.715 & 1.460 & 1.524 & 2.385 & 2.431 & -4.476 \\
\hline & sig. (2-taiedl) & 0.188 & 0.125 & 0.182 & 0.166 & 0.044 & 0.041 & 0.002 \\
\hline \multirow{3}{*}{ population } & Mean & 2.4 & 4.2 & 6.2 & 6.6 & 6.6 & 8.8 & 214.7 \\
\hline & Min & 0 & 0 & 1 & 1 & 0 & 5 & 202 \\
\hline & Max & 4 & 8 & 10 & 11 & 11 & 16 & 229 \\
\hline
\end{tabular}

\subsection{Output Value of Two Transplanting Modes}

It can be seen from Table 3 that the distribution of the modes and the annual economic indicators were basically similar to the population distribution. Generally, the variation of yield range $\left(115.35 \sim 203.33 \mathrm{Kg} / 666.7 \mathrm{~m}^{2}\right)$, value range $\left(3231.78 \sim 5845.74 ¥ / 666.7 \mathrm{~m}^{2}\right)$ and middle leaf rate range (20.66 38.37\%) were relatively large, while the super leaf rate and price were relatively stable. The yield and middle leaf rate were close to the normal distribution. The value and price were steep, and the middle leaf rate was symmetrical, while the distributions of others were left or right to normal.

The yield of YSTUPM ranged from 134.93 to 203.33 $\mathrm{Kg} / 666.7 \mathrm{~m}^{2}$, the value ranged from 3615.30 to 5458.74 $¥ / 666.7 \mathrm{~m}^{2}$, the middle leaf rate ranged from 20.66 to $32.00 \%$, and the coefficient variation of value, yield and middle leaf rate were $15.98 \%, 14.97 \%, 13.39 \%$, respectively.

For $\mathrm{CK}$, the coefficient variation of value ranged from 3231.78 to 4480.00 yuan $/ 666.7 \mathrm{~m}^{2}$, yield from 115.35 to $160.00 \mathrm{Kg} / 666.7 \mathrm{~m}^{2}$ and middle leaf rate from $25.17 \%$ to 
$38.37 \%$ were smaller than those of YSTUPM, and their variation coefficients were respectively $12.09 \%, 12.53 \%$ and $9.00 \%$. However, for the variation of middle leaf rate, the CK range $(25.17 \sim 38.37 \%, \mathrm{CV}: 15.96 \%)$ was larger than that of YSTUPM range $(20.66 \sim 32.00 \%$, CV: $13.39 \%)$.
In terms of year, the variation coefficients of yield, 12.62\% in 2013 were higher than $12.00 \%$ in 2014 , while other indicators were in 2013 higher than those in 2014, which CV of value $17.27 \%$ in $2014>$ that of $12.98 \%$ in 2013 , CV of middle leaves $14.71 \%$ in $2014>$ that of $13.17 \%$ in 2013 .

Table 3. Descriptive statistics of economic characters in transplanted modes and years.

\begin{tabular}{|c|c|c|c|c|c|c|c|c|}
\hline item & economic characters & Mean & SD & $\operatorname{Max}$ & Min & $\mathrm{CV}, \%$ & Kurtosis & Skewness \\
\hline \multirow[t]{5}{*}{ population } & yield, $\mathrm{Kg} / 666.7 \mathrm{~m}^{2}$ & 152.37 & 22.59 & 115.35 & 203.33 & 14.82 & 0.90 & 0.48 \\
\hline & value, $¥ / 666.7 \mathrm{~m}^{2}$ & 4137.85 & 673.98 & 3231.78 & 5845.74 & 16.29 & 2.07 & 1.08 \\
\hline & super leaf rate, $\%$ & 67.26 & 5.41 & 57.31 & 76.23 & 8.04 & -0.38 & -0.33 \\
\hline & middle leaf rate, $\%$ & 29.48 & 4.33 & 20.66 & 38.37 & 14.70 & 0.91 & 0.02 \\
\hline & price, $¥ / \mathrm{Kg}$ & 27.16 & 1.45 & 23.42 & 28.88 & 5.32 & 2.33 & -1.26 \\
\hline \multirow[t]{4}{*}{ YSTUPM } & yield, $\mathrm{Kg} / 666.7 \mathrm{~m}^{2}$ & 161.59 & 24.19 & 134.93 & 203.33 & 14.97 & 0.19 & 0.63 \\
\hline & super leaf rate, $\%$ & 69.83 & 3.75 & 66.62 & 76.23 & 5.37 & -0.60 & 0.86 \\
\hline & middle leaf rate, $\%$ & 28.45 & 3.81 & 20.66 & 32.00 & 13.39 & 3.31 & -1.68 \\
\hline & price, $¥ / \mathrm{Kg}$ & 27.67 & 1.01 & 26.07 & 28.88 & 3.66 & -0.66 & -0.40 \\
\hline \multirow{4}{*}{$\begin{array}{l}\text { CPAPM } \\
(\mathrm{CK})\end{array}$} & yield, $\mathrm{Kg} / 666.7 \mathrm{~m}^{2}$ & 143.15 & 17.94 & 115.35 & 160.00 & 12.53 & -1.04 & -0.81 \\
\hline & value, $¥ / 666.7 \mathrm{~m}^{2}$ & 3802.94 & 459.75 & 3231.78 & 4480.00 & 12.09 & -0.92 & 0.24 \\
\hline & super leaf rate, $\%$ & 64.69 & 5.82 & 57.31 & 72.09 & 9.00 & -1.52 & 0.16 \\
\hline & middle leaf rate, $\%$ & 30.51 & 4.87 & 25.17 & 38.37 & 15.96 & -0.72 & 0.50 \\
\hline \multirow[t]{5}{*}{2013} & yield, $\mathrm{Kg} / 666.7 \mathrm{~m}^{2}$ & 141.04 & 17.79 & 115.35 & 168.3 & 12.62 & -0.81 & 0.04 \\
\hline & value, $¥ / 666.7 \mathrm{~m}^{2}$ & 3890.37 & 504.83 & 3231.78 & 4690.74 & 12.98 & -0.86 & 0.16 \\
\hline & super leaf rate, $\%$ & 69.64 & 3.97 & 65.48 & 76.23 & 5.70 & -1.24 & 0.46 \\
\hline & middle leaf rate, $\%$ & 27.98 & 3.69 & 20.66 & 32.13 & 13.17 & 1.36 & -1.13 \\
\hline & price, $¥ / \mathrm{Kg}$ & 27.59 & 0.88 & 26.49 & 28.88 & 3.20 & -1.42 & 0.27 \\
\hline \multirow[t]{5}{*}{2014} & yield, $\mathrm{Kg} / 666.7 \mathrm{~m}^{2}$ & 167.47 & 20.10 & 145.80 & 203.33 & 12.0 & 1.969 & 1.207 \\
\hline & value, $¥ / 666.7 \mathrm{~m}^{2}$ & 4467.81 & 771.76 & 3718.29 & 5845.74 & 17.27 & 1.97 & 1.21 \\
\hline & super leaf rate, $\%$ & 64.09 & 5.72 & 57.31 & 72.00 & 8.93 & -1.67 & 0.19 \\
\hline & middle leaf rate, $\%$ & 31.48 & 4.63 & 25.36 & 38.37 & 14.71 & -0.32 & 0.25 \\
\hline & price, $¥ / \mathrm{Kg}$ & 26.58 & 1.91 & 23.42 & 28.75 & 7.19 & 0.42 & -0.79 \\
\hline
\end{tabular}

Table 4. T-test of economic characters in transplanted modes and years.

\begin{tabular}{|c|c|c|c|c|c|c|}
\hline item & compare & yield, $\mathrm{Kg} / 666.7 \mathrm{~m}^{2}$ & value, $¥ / 666.7 \mathrm{~m}^{2}$ & super leaf rate, $\%$ & middle leaf rate, $\%$ & price, $¥ / \mathbf{K g}$ \\
\hline \multirow{6}{*}{ treatment } & YSTUPM & 161.59 & 4472.75 & 69.83 & 28.45 & 27.67 \\
\hline & $\mathrm{CK}$ & 143.15 & 3802.94 & 64.69 & 30.51 & 26.64 \\
\hline & different & 18.44 & 669.81 & 5.14 & -2.05 & 1.03 \\
\hline & relative different, $\%$ & 12.88 & 17.61 & 7.95 & -0.879 & 3.88 \\
\hline & $T$-test & 1.619 & 2.085 & 1.965 & 0.397 & 1.383 \\
\hline & Sig. (2-tailed) & 0.131 & 0.050 & 0.073 & 6.73 & 0.192 \\
\hline \multirow{6}{*}{ year } & 2014 & 167.47 & 4467.81 & 64.09 & 31.48 & 26.58 \\
\hline & 2013 & 141.04 & 3890.37 & 69.64 & 27.98 & 27.59 \\
\hline & different & 26.43 & 577.44 & -5.56 & 3.49 & -1.01 \\
\hline & relative different, $\%$ & 18.74 & 14.84 & -7.98 & 12.49 & -3.66 \\
\hline & $T$-test & -2.605 & -1.697 & 2.153 & -1.576 & 1.330 \\
\hline & Sig. (2-tailed) & 0.023 & 0.115 & 0.052 & 0.141 & 0.208 \\
\hline
\end{tabular}

It can be seen from Tables 3 4 that YSTUPM mode would effectively improve the economic character of flue-cured tobacco leaves. The yield, value, superior leaf ratio, price of YSTUPM was superior to that of CK. The relative effects were expressed as relative different, which increased by $12.88 \%, 17.61 \%, 7.95 \%$, and $3.88 \%$, respectively, of which the value took a significant effect.
Between the years, the middle leaf rate, yield and value in 2014 were higher than that in 2013 , which was $18.74 \%$, $14.84 \%$, and $12.49 \%$ higher respectively, while the superior leaf rate and price in 2014 were slightly lower than that in 2013, which was $7.98 \%$ and $3.66 \%$ lower, respectively. Among them, the yield and the superior leaf rate were significantly different. 


\subsection{Basic Meteorological Features of Baoshan Tobacco-growing Area}
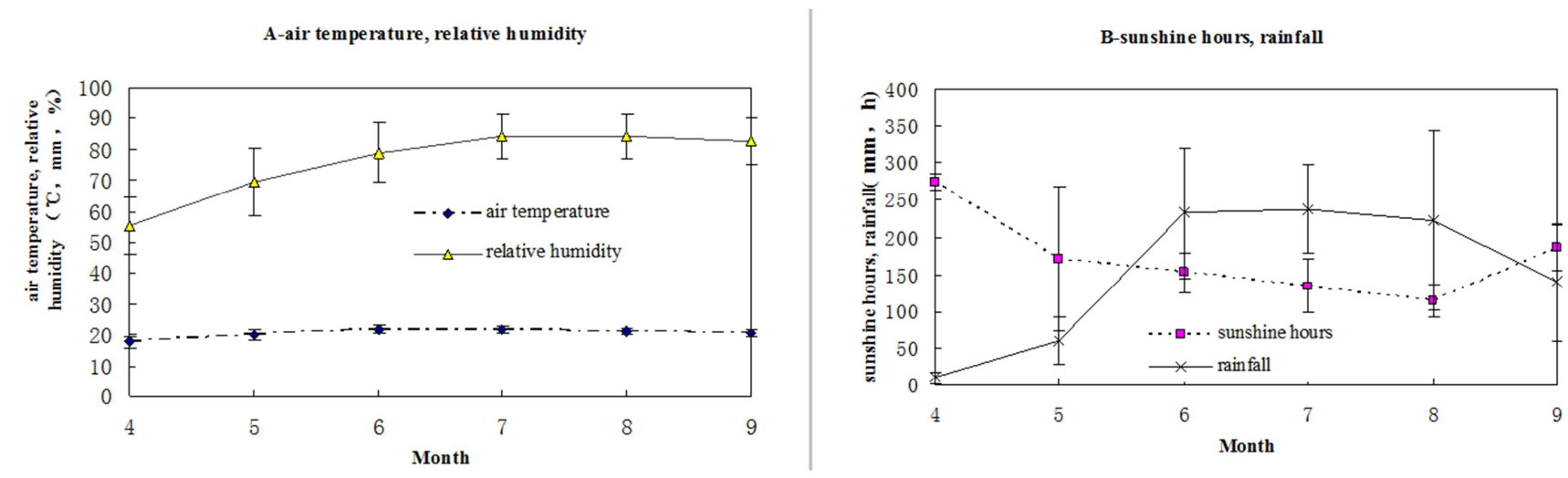

Figure 1. The main climatic factors variation during the field growth period in Baoshan tobacco-growing area A- air temperature, relative humidity, Bsunshine hours, rainfall.

From the change of monthly climatic factors in the whole field growth period (Figure 1), it can be seen that the typical low-latitude plateau monsoon climate in Baoshan tobacco-growing area is embodied by rainy season coincided with high temperature. The trend of relative humidity and air temperature is consistent. The variation of climatic factors in each month is mainly rainfall and sunshine. Rainfall generally increased in the field period, and rainfall was concentrated in the main flood season of June, July and August, with different amount monthly rainfall ranges, while sunshine hours and rainfall presented a significant negative correlation $\left(r=-0.857^{* *}\right)$.

The temperature in the field growth period in Baoshan tobacco-growing area gradually increased steadily after transplanting, rising from an average temperature of $17.7^{\circ} \mathrm{C}$ in April to $21.9^{\circ} \mathrm{C}$ in June, and then maintained above $20.0^{\circ} \mathrm{C}$, and decreased slightly in September. There was no significant difference in temperature between each month during the whole field growth period, which the coefficient of variation was only $7.55 \%$. However, the coefficient of variation of temperature changes in April and May in Baoshan was more than the difference in the whole field growth period. The specific performance is as follows: April (CV: 9.53\%) > May (CV: 8.04\%) > June (CV: 6.37\%) > July (CV: 5.43\%) > September (CV: $4.52 \%)>$ August (CV: $4.92 \%$ ).

The sunshine hours of each month after transplanted in Baoshan tobacco-growing area, it gradually decreased steadily and then increased slightly in August. Sunshine hours reached $274.34 \mathrm{~h}$ in April. With coming of the rainy season, sunshine hours per month decreased, which was only $114.3 \mathrm{~h}$ in August. In the whole field growth period, there was a large difference between the sunshine hours of each month, and the coefficient variation was $32.62 \%$. However, the coefficient of variation of temperature changes in May in Baoshan was more than the difference in the whole field growth period. The specific performance is as follows: May $(\mathrm{CV}: 57.06 \%)>$ July $(\mathrm{CV}: 26.65 \%)>$ August (CV: 18.80\%) $>$ June (CV: $17.45 \%)>$ September (CV: 15.91\%) > April (CV: $4.01 \%)$.
In Baoshan tobacco-growing area, the relative humidity of air in each month gradually increased after transplanted, but decreased slightly in August. The relative humidity in April was $55.4 \%$ and increased with the arrival of the rainy season, reaching as high as $84.4 \%$ in July. In the whole field growth period, there was a large difference between the relative humidity of each month, and the coefficient variation was $15.36 \%$. The coefficient variation of relative humidity in April and May in Baoshan was more than the difference in the whole field growth period. The specific performance is as follows: May (CV: 16.72\%) > April (CV: 15.61\%) > June (CV: 12.04\%) > September (CV: 9.13\%) > August (CV: $8.62 \%)>$ July (CV: 8.36\%).

In the field period of Baoshan tobacco-growing area, the monthly rainfall increased gradually after the transplant, and it decreased slightly in August. The rainfall in April was $10.02 \mathrm{~mm}$, and the monthly rainfall increased with the arrival of the rainy season. June, July and August were the main flood season with rainfall concentration, and the maximum reached $238.68 \mathrm{~mm}$ in July. The difference between the rainfalls of the whole field during the growing period was the largest with a coefficient variation of $64.97 \%$. The coefficient of variation of rainfall in April in Baoshan was more than the difference in the whole field growth period. The specific performance is as follows: April (CV: 77.19\%) > September $(\mathrm{CV}: 56.16 \%)>$ August (CV: $54.21 \%)>$ May $(\mathrm{CV}: 53.85 \%)>$ June (CV: $37.79 \%)>$ July (CV: 25.26\%).

\subsection{Relationship Between Meteorological Factors and Growth Stages in Baoshan Tobacco-growing Area}

The results of index selection after correlation analysis of 6 types of 40 meteorological factors and their combination data and growth period are shown in table 5. There was a significant positive correlation between the days from transplantation to the root spreading stage and the product of accumulation value of air temperature and sunshine hours in the root spreading stage $\left(r=0.727^{* *}\right)$.

The days from transplantation to the fast growing period showed a highly significant negative correlation with the 
daily mean of rainfall in the fast growing period $\left(r=-0.723^{* *}\right)$ and the product by daily mean of air temperature and sunshine hours and rainfall in the fast growing period $\left(r=-0.764^{* *}\right)$, a significant negative correlation with the accumulation value of temperature in the fast growing period $\left(r=-0.693^{*}\right)$, while a highly significant positive correlation with sunshine hours in the fast growing period $\left(r=0.710^{* *}\right)$.

The days from transplanting to maturity stage showed a significant positive correlation with the daily mean of sunshine hours in the maturity stage $\left(r=0.673^{*}\right)$ and the accumulation value of sunshine hours in the maturity stage $\left(r=0.675^{*}\right)$.

Table 5. Pearson correlation of meteorological factors with days of transplanted of the stages.

\begin{tabular}{|c|c|c|c|c|}
\hline meteorological index & Correlation & root spreading stage & fast growing period & maturity stage \\
\hline$\sum \mathrm{P}(\mathrm{T} \times \mathrm{L})$ root spreading & $\begin{array}{l}r \\
\text { Sig. (2-tailed) }\end{array}$ & $\begin{array}{l}0.727\left(^{* *}\right) \\
0.007\end{array}$ & & \\
\hline $\mathrm{dR}_{\text {fast growing }}$ & $\begin{array}{l}r \\
\text { Sig. (2-tailed) }\end{array}$ & & $\begin{array}{l}-0.723\left({ }^{* *}\right) \\
0.008\end{array}$ & \\
\hline$\sum \mathrm{L}_{\text {fast growing }}$ & $\begin{array}{l}r \\
\text { Sig. (2-tailed) }\end{array}$ & & $\begin{array}{l}0.710\left(^{* *}\right) \\
0.010\end{array}$ & \\
\hline$\sum \mathrm{T}_{\text {fast growing }}$ & $\begin{array}{l}r \\
\text { Sig. (2-tailed) }\end{array}$ & & $\begin{array}{l}-0.693\left(^{*}\right) \\
0.012\end{array}$ & \\
\hline$\sum \mathrm{P}(\mathrm{dT} \cdot \mathrm{dL} \cdot \mathrm{dR})_{\text {fast growing }}$ & $\begin{array}{l}r \\
\text { Sig. (2-tailed) }\end{array}$ & & $\begin{array}{l}-0.764\left(^{* *}\right) \\
0.004\end{array}$ & \\
\hline $\mathrm{dL}_{\text {maturity }}$ & $\begin{array}{l}r \\
\text { Sig. (2-tailed) }\end{array}$ & & & $\begin{array}{l}0.673\left(^{*}\right) \\
0.016\end{array}$ \\
\hline$\sum \mathrm{L}_{\text {maturity }}$ & $\begin{array}{l}r \\
\text { Sig. (2-tailed) }\end{array}$ & & & $\begin{array}{l}0.675\left(^{*}\right) \\
0.016\end{array}$ \\
\hline
\end{tabular}

Notes: ${ }^{* *}$ Correlation is significant at the 0.01 level (2-tailed), ${ }^{*}$ Correlation is significant at the 0.05 level (2-tailed). same as the follow.

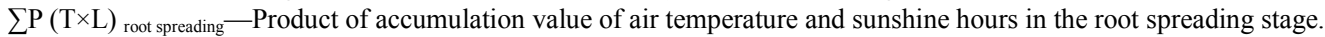

$\mathrm{dR}_{\text {fast growing }}$-Daily mean of rainfall in the fast growing period.

$\sum \mathrm{L}_{\text {fast growin }}$-Accumulation value of sunshine hours in the fast growing period.

$\sum \mathrm{T}_{\text {fast growing }}$-Accumulation value of air temperature in the fast growing period.

$\sum \mathrm{P}(\mathrm{dT} \times \mathrm{dL} \times \mathrm{dR})$ fast growing - Product by daily mean of air temperature and sunshine hours and rainfall in the fast growing period.

$\mathrm{dL}_{\text {maturity }}$-Daily mean of sunshine hours in the maturity stage.

$\sum \mathrm{L}_{\text {maturity }}$-Accumulation value of sunshine hours in the maturity stage.

\subsection{Relationship Between Meteorological Factors and Economic Characters in Baoshan Tobacco-growing Area}

Table 6 Pearson correlation of meteorological factors with economic characters

\begin{tabular}{|c|c|c|c|c|c|c|}
\hline meteorological index & Correlation & yield & value & super leaf & middle leaf & price \\
\hline $\mathrm{dT}_{\text {whole growing }}$ & $\begin{array}{l}r \\
\text { Sig. (2-tailed) }\end{array}$ & $\begin{array}{l}0.773\left(^{* *}\right) \\
0.003\end{array}$ & & & & $\begin{array}{l}-0.926\left(^{* *}\right) \\
0.0001\end{array}$ \\
\hline$\sum \mathrm{T}_{\text {whole growing }}$ & $\begin{array}{l}r \\
\text { Sig. (2-tailed) }\end{array}$ & $\begin{array}{l}0.880\left(^{* *}\right) \\
0.0001\end{array}$ & $\begin{array}{l}0.675\left(^{*}\right) \\
0.016\end{array}$ & & & $\begin{array}{l}-0.745\left(^{* *}\right) \\
0.005\end{array}$ \\
\hline$\sum \mathrm{P}(\mathrm{dT} \times \mathrm{dL})$ whole growing & $\begin{array}{l}r \\
\text { Sig. (2-tailed) }\end{array}$ & $\begin{array}{l}0.888\left(^{* *}\right) \\
0.0001\end{array}$ & $\begin{array}{l}0.825\left(^{* *}\right) \\
0.001\end{array}$ & & & \\
\hline$\sum \mathrm{P}(\mathrm{T} \times \mathrm{L})$ whole growing & $\begin{array}{l}r \\
\text { Sig. (2-tailed) }\end{array}$ & & $\begin{array}{l}0.707\left(^{*}\right) \\
0.010\end{array}$ & & & \\
\hline$\sum \mathrm{P}(\mathrm{T} \times \mathrm{L})$ fast growing & $\begin{array}{l}r \\
\text { Sig. (2-tailed) }\end{array}$ & & & $\begin{array}{l}0.629\left(^{*}\right) \\
0.028\end{array}$ & $\begin{array}{l}-0.653\left(^{*}\right) \\
0.021\end{array}$ & \\
\hline$\sum \mathrm{L}_{\text {fast growing }}$ & $\begin{array}{l}r \\
\text { Sig. (2-tailed) }\end{array}$ & & & & & \\
\hline$\sum \mathrm{P}(\mathrm{dT} \times \mathrm{dL} \times \mathrm{dR})$ whole growing & $\begin{array}{l}r \\
\text { Sig. (2-tailed) }\end{array}$ & & & & $\begin{array}{l}-0.601\left(^{*}\right) \\
0.039\end{array}$ & $\begin{array}{l}-0.590\left(^{*}\right) \\
0.044\end{array}$ \\
\hline$\sum \mathrm{P}(\mathrm{T} \times \mathrm{L} \times \mathrm{R})$ whole growing & $\begin{array}{l}r \\
\text { Sig. (2-tailed) }\end{array}$ & & & & & $\begin{array}{l}-0.666\left(^{*}\right) \\
0.018\end{array}$ \\
\hline
\end{tabular}

Notes:

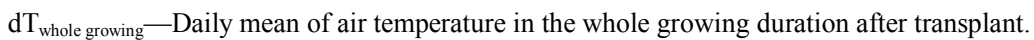

$\sum \mathrm{T}_{\text {whole growing }}$-Accumulation values of air temperature in the whole growing duration after transplant.

$\sum \mathrm{P}(\mathrm{dT} \times \mathrm{dL})$ whole growing - Product by daily mean of air temperature and sunshine hours in the whole growing duration after transplant.

$\sum \mathrm{P}(\mathrm{T} \times \mathrm{L})$ whole growing - Product by accumulation value of air temperature and sunshine hours in the whole growing duration after transplanted.

$\sum \mathrm{P}(\mathrm{T} \times \mathrm{L})$ fast growing - Product by accumulation value of air temperature and sunshine hours in the fast growing period.

$\sum \mathrm{L}_{\text {fast growing }}$-Accumulation value of sunshine hours in the fast growing period.

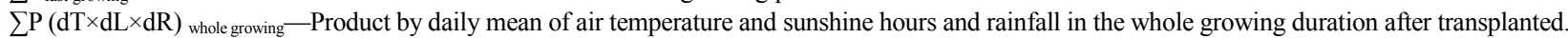

$\sum \mathrm{P}(\mathrm{T} \times \mathrm{L} \times \mathrm{R})$ whole growing - Product by accumulation value of air temperature and sunshine hours and rainfall in the whole growing duration after transplanted.

The results of index selection after correlation analysis between 6 types of 40 meteorological factors and their combination data and economic index are shown in table 6.

The daily mean of air temperature in the whole growing 
duration after transplanted showed a significant positive correlation with yield, while a highly significant negative correlation with price. The accumulation values of air temperature in the whole growing duration after transplanted showed a highly significant positive correlation with yield, a significant positive correlation with value, while a highly significant negative correlation with price. The product by daily mean of air temperature and sunshine hours in the whole growing duration after transplanted showed a highly significant positive correlation with yield and value. The product by accumulation value of air temperature and sunshine hours in the fast growing period showed a significant positive correlation with super leaf rate, while a significant negative correlation with middle leaf rate. The product by daily mean of air temperature and sunshine hours and rainfall in the whole growing duration after transplanted showed a significant negative correlation with middle leaf rate and price.

Yield showed a highly significant positive correlation with the daily mean of air temperature in the whole growing duration $\left(r=0.773^{* *}\right)$, accumulation values of air temperature in the whole growing duration $\left(r=0.880^{* *}\right)$ and product by daily mean of air temperature and sunshine hours in the whole growing duration $\left(r=0.888^{* *}\right)$. Value showed a highly significant positive correlation with product by daily mean of air temperature and sunshine hours in the whole growing duration $\left(r=0.825^{* *}\right)$, and a significant positive correlation with the product by accumulation value of air temperature and sunshine hours $\left(r=0.707^{*}\right)$ and the accumulation value of air temperature $\left(r=0.880^{* *}\right)$ in the whole growing duration. The super leaf ratio showed a significant positive correlation with the product by accumulation value of air temperature and sunshine hours in the fast growing period $\left(r=0.629^{*}\right)$. The middle leaf ratio showed a significant negative correlation with the accumulation value of sunshine hours in the fast growing period $\left(r=-0.653^{*}\right)$ and the product by daily mean of air temperature and sunshine hours and rainfall in the whole growing duration after transplanted $\left(r=-0.601^{*}\right)$. Price has a highly significant negative correlation with the daily mean of air temperature $\left(r=-0.926^{* *}\right)$ and the accumulation values of air temperature $\left(r=-0.745^{* *}\right)$ in the whole growing duration after transplanted, and a significant negative correlation with product by daily mean of air temperature and sunshine hours and rainfall $\left(r=-0.590^{*}\right)$ and product by accumulation value of air temperature and sunshine hours and rainfall $\left(r=-0.666^{*}\right)$ in the whole growing duration after transplanted.

\section{Discussion}

The whole growth period of YSTUPM were actually shortened by $16.2 \mathrm{~d}$ compared with the CK. The days from transplant to 1th picked-cured and final picked-cured, the YSTUPM were significantly longer than conventional mode. While for the whole growth period, the YSTUPM were significantly shorter than conventional mode. YSTUPM were significantly shorter than CPAPM in the whole growth period, and the results were basically consistent with relevant reports $[35,48]$. In the growing period of field, YSTUPM were significantly longer than the conventional mode, which was consistent with the reports of Zhou Li [4], Li Qiuying [9] and etc., but not with $\mathrm{Bu}$ Yunhong et al $[8,34,36,49]$. This may be related to the differences in the experimental meteorological conditions, cultivars and their seedling age, the interval between the two transplanting modes, and the management level.

YSTUPM would effectively improve the economic character of flue-cured tobacco leaves, and its yield, value, superior leaf rate, price and other index were superior to conventional mode, which was consistent with the reported results.

In terms of the common single index of meteorological factors, in the fast growing period, DAT to the period had a highly significant negative correlation with the daily mean of rainfall $\left(r=-0.723^{* *}\right)$, with the accumulation value of air temperature $\left(r=-0.693^{*}\right)$, while a highly significant positive correlation with sunshine hours $\left(r=0.710^{* *}\right)$; in the maturity stage, a significant positive correlation with the daily mean of sunshine hours $\left(r=0.673^{*}\right)$ and the accumulation value of sunshine hours $\left(\mathrm{r}=0.675^{*}\right)$. However, In terms of the combined index of constructed meteorological elements, there was a highly significant positive correlation between DAT to the root spreading stage and the product of accumulation value of air temperature and sunshine hours in the root spreading stage $\left(r=0.727^{* *}\right)$, while DAT to the fast growing period showed a highly significant negative correlation with the product by daily mean of air temperature and sunshine hours and rainfall in the fast growing period $\left(r=-0.764^{* *}\right)$. It indicated that the daily mean of rainfall, the accumulation values of air temperature and the sunshine hours in the fast growing period had a direct influence on DAT to the fast growing period, and the rainfall had a decisive influence on the period. The daily mean of sunshine hours and the accumulation value of sunshine hours in the maturity stage had direct influence on DAT to the maturity stage.

This also confirmed that reported result "more sunshine hours were been required in early growth, help to increased dry matter accumulation, extended growth days, and a positive correlation with sunshine hours" $[50,51]$. DAT to the maturity stage and the accumulation value of sunshine hours in the maturity stage showed a significant positive correlation, which was consistent with the results of Xie Jingming et al. [52]. The characteristics of flue-cured tobacco growth demand water are less in the early stage, more in the middle stage and less in the late stage. Precipitation during the period of transplanting is more beneficial to seedling restitution, and less soil moisture after seedling restitution is more beneficial to rooting. Sufficient moisture in the fast growing period can promote the vigorous growth of tobacco plants. Less rainfall during the maturity stage of tobacco leaves is conducive to timely yellowing and maturity of tobacco leaves [53]. The relationship between the index of daily mean of rainfall and 
the computed rainfall index and growth period also accords with the relevant theories.

However, there were significant positive correlation the combination index of the meteorological elements with economic index, which including yield with the product by daily mean of air temperature and sunshine hours in the whole growing duration $\left(r=0.888^{* *}\right)$, Value with product by daily mean of air temperature and sunshine hours in the whole growing duration $\left(r=0.825^{* *}\right)$ and with the product by accumulation value of air temperature and sunshine hours $\left(r=0.707^{*}\right)$, the super leaf rate with the product by accumulation value of air temperature and sunshine hours in the fast growing period $\left(r=0.629^{*}\right)$; while highly significant negative correlation, which including the middle leaf ratio with the accumulation value of sunshine hours in the fast growing period $\left(r=-0.653^{*}\right)$ and the product by daily mean of air temperature and sunshine hours and rainfall in the whole growing duration after transplanted $\left(r=-0.601^{*}\right)$, Price with product by daily mean of air temperature and sunshine hours and rainfall $\left(r=-0.590^{*}\right)$ product by accumulation value of air temperature and sunshine hours and rainfall $\left(r=-0.666^{*}\right)$ in the whole growing duration after transplanted. Among them, The significant positive correlation of the product by accumulation value of air temperature and sunshine hours in the fast growing period with the super leaf rate, was not consistent with the results of Xie Jingming et al, which the super leaf rate showed negative correlation with the sunshine hours, while showed positive correlation with the net dry matter accumulation [52].

The differences of single meteorological factor and their combinations may be the main reason for the differences of growth and production value of flue-cured tobacco under the two transplanting modes. It is necessary to make a comparative study on the growth and development rules, dry matter accumulation, yield and quality factors formation, soil nutrient dynamics and meteorological factors consistency with the growth and development requirements of tobacco plants, so as to improve the technical system of YSTUPM. Meteorological factors not only affect the growth period and economic indicators directly, but also result to the comprehensive influence of multiple factors. The theory of accumulated temperature argues that a certain amount of accumulated temperature is needed to the life cycle of crops. When the activity or effective accumulated temperature does not reach the normal growth and development of tobacco, the growth period is prolonged, which directly affects the yield and quality of tobacco [54]. Therefore, from the perspective of plant ecology, experiments in different regions should be compared with comprehensive indicators such as accumulated temperature, which can increase its explanatory and mechanistic. In this paper, it is found that some meteorological factor combination indexes, such as light-temperature accumulation, temperature-rainfall accumulation, light-temperature-rainfall accumulation, were significantly related to growth period and economic characters.

\section{Conclusion}

This study shows that there were direct relation of the accumulation values of air temperature in the whole growing duration, product by daily mean of air temperature and sunshine hours with yield, value, price; daily mean of air temperature in the whole field growing duration with yield, product by daily of air temperature and sunshine hours with the output value, the product by accumulation value of air temperature and sunshine hours in the fast growing period with the super leaf rate, the product by daily mean of air temperature and sunshine hours and rainfall in the whole growing duration after transplanted with the middle leaf rate, the product by accumulation value of air temperature and sunshine hours and rainfall in the whole growing duration after transplanted with price. The growth period and economical characters affected by not only single sunshine, rainfall, temperature factor, but also much combined factors by time lasting.

\section{Acknowledgements}

The research is supported by Science and Technology Project of China Tobacco Yunnan Company (2018530000242012) and (2013YN32).

\section{References}

[1] Cao J L, Zhou D G, Wang Q L, Zhou Y B, Wang S J. Talking about several technical problems of flue-cured tobacco in Huaibei Area [J]. Tobacco Science \&Technology, 1997, (3): 41-43.

[2] Wang X Z, Zhu G Z. Two dry tobacco farming techniques in hilly and mountainous areas of western Henan [J]. Tobacco Science \&Technology, 1992, (1): 41-42.

[3] Yang J T. Research and application of transplanting technology of transplanting young tobacco seedlings under film [D]. Beijing: Chinese Academy of Agricultural Sciences, 2008, 1-35.

[4] Zhou L, Li H G, Fu Y L. Advantages and main technical analysis of transplanting young tobacco seedlings under film [J]. Anhui Agricultural Science Bulletin, 2012, 18 (03): 42-43, 60 .

[5] Tao Y, Zheng J M, Huang W, Liu Y. Climatic characteristics of Yunnan's drought in later spring and early summer [J]. Journal of Natural Disasters, 2009, 18 (1): 24-132.

[6] Wu D X, Yang C, Li F, Ren G M, Li N. Effects of leaf-cutting methods on the virus spread in flue-cured tobacco floating-seedling system [J]. Journal of Yunnan Agricultural University, 2008, 23 (2): 257-259.

[7] $\mathrm{Xu} X \mathrm{Y}$. Continuous drought and disease have spawned new changes in Yunnan tobacco cultivation technology [EB/OL]. [2014-04-14]. http: //www.yntsti.com.

[8] $\mathrm{Bu}$ Y H, Zhang Y C, Hu X D, Chen G. Effects of transplanting small seedling under plastic film mulching on growth and development of flue-cured tobacco [J]. Acta Agriculturae Jiangxi, 2013, 25 (4): 157-160. 
[9] Li Q Y, Xu D S, Wang P, Yang L F, Lin S W, Deng J W, Dong W G, Xing Y W. The influence of tobacco seedling transplanting above plastic mulching and that under plastic mulching on the growth of flue-cured tobacco and the quality of tobacco leaf $[\mathrm{J}]$. Chinese Agricultural Science Bulletin, 2014, 30 (4): 170-174.

[10] Chen Z L, Liu G, Feng Y L, Wang W. Effects of transplanting method on growth development, yield and quality of flue-cured tobacco in Meizhou region [J]. Journal of Anhui Agricultural Science, 2017, 45 (24): 39-43.

[11] Zhang G P, Shen C Y, Xiao X Y, Liu Y, Yang Q G, Rao W P, Wang W, Lian $\mathrm{H}$, Zhong Q Z. Effects of different transplanting methods on Yield and quality of flue-cured tobacco in Ganzhou Tobacco-growing Region [J]. Bulletin of Agricultural Science and Technology, 2018, (3): 107-111.

[12] Lei J Z, Hou Y. Comparative study on transplanting and transplanting of seedlings under film mulch of flue-cured $[\mathrm{J}]$. Modern Agricultural Science and Technology, 2016, (1): 36-38.

[13] Wang Z R, Liu Y, Peng Y D, Shen C Y, Yang Q G, Hu Y C, Xu Q K, Zhong Q Z, Xiao X Y, Li Z Y, Liu X P. Effects of different transplanting methods on yield and quality of flue-cured tobacco [J]. Acta Agriculturae Jiangxi, 2015, 27 (11): 31-34.

[14] Dong X M, Yang J H, Yan Z H, Shao W X, Hu Z M, Li F L. Yield and quality effects of flue-cured tobacco of three kinds of plastic films under early-planted film-covered transplanted mode [J]. Journal of Anhui Agricultural Sciences, 2013, 41 (23): 9567-9568.

[15] Dong J, Ding C. Effects of seedling transplanting under different color film on the yield and output value of flue-cured tobacco [J]. Modern Agricultural Science and Technology, 2015, (7): 21-22.

[16] Xue X P, Yang T P, Fu J G. Membrane small arch shed structure after transplanting tobacco seedlings in the field [P]. Chinese Patent, 2012. CN202285715U.

[17] Zhang L M, Zhu W Q. Effects of size germinating methods on field growth and economic character of small flue-cured tobacco seedlings transplanting under membrane [J]. Journal of Anhui Agricultural Sciences, 2015, 43 (5): 56-57, 90.

[18] Xu X Y, Zhu M, Ouyang J, Qin C L, Yang Z Q, Deng Q, Yang L Q. Effects of different size germinating trays on tobacco young seedlings quality [J]. Journal of Kunming University, 2014, 36 (3): 21-23.

[19] Zhao F, Yang J Z, Chen X, Tao Y P, Shi L, Zheng L H, Jiang Z P, Qian W Y, Wang Y, Gong C L, Wu A, Cui D. Impact of different irrigation-before-transplanting methods on growth, yield and quality of under-film tobacco seedlings [J]. Journal of Anhui Agricultural Sciences, 2014 (42 (33): 11657-11659.

[20] Dong X M, Hu Z M, Yan Z H, Cheng C X, Fan Y C, Li F L. Effects of plastic film mulching and straw mulching on the growth and yield of early-plant tobacco [J]. Journal of Anhui Agricultural Sciences, 2013, 41 (22): 9211-9212, 9237.

[21] Sun K, Li Y D, Zhang J, Li W, Lu Y, Wang J X. Effects of transplant seedling under plastic mulching and different removing film and hilling time on the quality of early-planted flue-cured tobacco [J]. Journal of Anhui Agricultural Science, 2018, 46 (31): $23-25+33$.
[22] Zhang G F, Yang Z, Wang S Q, Sun J L, Fan J. Effects of different time of film mulch of transplanted seedlings under plastic film on growth, yield and quality [J]. Modern Agricultural Science and Technology, 2017, (12): 7-9.

[23] Zhou L, Pan Y H, Fu Y L, Li H G, Pu E P, Sun S H, Yang X L. Effect of Transplanting Tobacco Seedlings under Plastic Film at Different Ages on Tobacco Growth and Quality [J]. Southwest China Journal of Agricultural Sciences, 2015, 28 (4): $1612-1616$

[24] Huang J, Zhang H W, Lu R J. Effects of transplanting time on yield and quality of flue-cured tobacco K326 in south of Jiangxi province $[\mathrm{J}]$. Acta Agriculturae of Jiangxi, 2014, 26 (3): 61-64.

[25] Mu Y, Yang Z J, He Q, Guo S M. Comparative experiment on seedling transplanting of flue-cured tobacco under different transplanting stages [J]. Anhui Agricultural Science Bulletin, 2014, 20 (7): 62-63.

[26] Su P F, Li Y C, Shen X T, Zheng M, Ling P, Peng T J. Effects of Transplanting Time and Modes on Growth, Yield and Quality of Flue-cured Tobacco [J]. Guizhou Agricultural Sciences, 2016, 44 (11): 51-55.

[27] Yang J Z, Li W L, Zhao F, Chen X, Tao Y P, Shi Y P, Cao L B. Suitable Transplanting Time of Tobacco Young Seedlings under Film Cover in Zhaotong Warm-keeping Tobacco-planting Region [J]. Guizhou Agricultural Sciences, 2016, 44 (9): 51-55.

[28] Li J F, Li L H, Ma J H, Dong K L, Miao P, Ye H C, Zhao S M, Jiang K, Wang W. Effect of Transplanting Tobacco Seedlings under Plastic Film on Tobacco Growth and Production and Quality [J]. Journal of Anhui Agricultural Science, 2017, 45 (32): $14-16$.

[29] Zhou Z L, Yang Q Y, Zhang L B, Chen M, Zhang L Q. Effects of different fertilization methods on seedling transplanting of Flue-cured Tobacco under film [J]. Jilin Agricultural, 2019, 5: 71-72.

[30] Luo J Q, Zeng X N, Liu J Y. Effects to the Transplanting Tobacco Seedlings Beneath Plastic Film Under Different Fertilization Method [J]. Hunan Agricultural Sciences, 2017, (3): 23-26.

[31] Liu Y, Yang S B, Wang J Y, Bai Y Y, Wang L. Effect of Different Ratios of Organic Base Fertilizer Applied With Compound Fertilizer on Yield and Quality of Flue-cured Tobacco Seedlings Under Mulch [J]. Chinese Agricultural Science Bulletin, 2016, 32 (15): 139-143.

[32] Yang J Z, Zhao F, Zheng L H, Chen X, Tao X P, Qian W Y, Li W L, Liu C X. Effects of different fertilization methods on growth and yield of tobacco leaves under transplanting seedlings of flue-cured tobacco [J]. Journal of Zhejiang Agricultural Sciences, 2014, 10: 1525-1527.

[33] Zhou L, Yin Y P, Lin Y F, Pu E P, Sun S H, Zhang Y H, Pu H, Wang M, Ma H F. Method for water-saving transplanting of flue-cured tobacco seedlings under drought and little rain conditions [P]. Chinese Patent, 2012. CN102405758A (CN201110292191. X).

[34] Song G H, Chen Y G, Wang H T, Li C J, Li S J. Studies on protective cultivation technology of flue-cured tobacco seedlings transplanting under mulch for aphid avoiding and tobacco virus diseases prevention $[\mathrm{J}]$. Journal of Henan Agricultural Sciences, 2013, 42 (8): 82-85. 
[35] Liu G Y, Yang J T, Tian L, Pei J, Wen L, Liu W T, Wu B. Effect of transplanting tobacco seedlings under plastic film on tobacco growth, soil moisture and temperature $[\mathrm{J}]$. Chinese Tobacco Science, 2012, 33 (6): 27-32.

[36] Kong Y L. Effects of transplanting young tobacco seedlings under film on viral diseases prevention, growth, development, and economic characters of flue-cured tobacco [J]. Tobacco Science \& Technology, 2011, (9): 75-80.

[37] Lv J F, You T G, Fang D H, Chen X, Huang Y H, Xie M L, Yin Y R, Zhai C L, Ma Y R, Ma Y F. Effects of different cultivation methods on the occurrence of tobacco black shank [J]. Journal of Zhejiang Agricultural Sciences, 2014, (8): 1219 , 1221.

[38] Li Y, Zhang D Z. Research on healthy cultivation technique controlling tobacco black shank [J]. Modern Agricultural Sciences and Technology, 2011 (24): 183, 188.

[39] Zhang J, Pan H P, Yang T P, Xue X P, Long Q R, Liu S G. Preliminary study on flue-cured tobacco seedling-rearing modes of small seedlings transplanting methods under the membrane $[\mathrm{J}]$. Guangdong Agricultural Sciences, 2013, (1): 24-26.

[40] Men F Y. Preliminary study on cultivation techniques of winter tobacco seedlings in Lianghe County [J]. South China Agriculture, 2015, 9 (3): 40-41.

[41] $\mathrm{Hu} \mathrm{Z} \mathrm{C.} \mathrm{Seedling} \mathrm{cultivation} \mathrm{techniques} \mathrm{of} \mathrm{flue-cured} \mathrm{tobacco}$ in Wenshan Prefecture [J]. Yunnan Agricultural Science and Technology, 2014, (4): 31-32.

[42] Chen X, Shi L, Yuan K, Wang K P. Discussion on the technology of flue-cured tobacco seedling transplant under plastic film [J]. Journal of Anhui Agricultural Sciences, 2014, 42 (7): 1963-1964, 1972.

[43] Wang $\mathrm{K} \mathrm{H}$. Tobacco membrane seedling transplanting technology in Weifang [J]. Modern Agricultural Science and Technology, 2012, (2): 58, 61.

[44] Wang W, Zheng M. Localization research on transplanting technology of seedlings under film mulch of flue-cured tobacco [J]. Modern Agricultural Sciences and Technology, 2018, (14): 9-10, 12.
[45] Li J, Zhang J, Li W, He Y, Yang Y M, Dong S F, Liu C K, Zhang J S. Effects of Different Altitude on Growth Physiology of Flue-cured Tobacco Under Transplanting Seedlings [J]. Farm Products Processing, 2018, (6): 48-52.

[46] Liu Y W. Study on micro-meteorological characteristics of transplanted tobacco film [J]. Journal of Shanxi Meteorology, 1992, (2) 33-36.

[47] Wang Y T, Xie J P, Li Z H. China tobacco planting areas [M]. Beijing: Science Press, 2010, 1: 155, 179.

[48] Li Z G, Zou J M, Xu F H. Application and promotion of transplanting technology of flue-cured tobacco seedlings in Dali Prefecture [J]. Yunnan Tobacco, 2013, (3): 51-54.

[49] Yunnan Academy of Tobacco Agricultural Sciences. Matching techniques for transplanting seedlings under flue-cured tobacco (Part II) [J]. Rich World, 2013, (6): 46-47.

[50] Zhang G, Zhu L S, Wang K W, Tu N M, Xu J Q. Advances in research on the effects of major meteorological factors on tobacco growth and development [J]. Crop Research, 2006, (5): 486-489.

[51] Chen Z Y, Wang Y. Ecological Adaptation for the Evaluation of Cultivation Flue-cured Tobacco [M]. Beijing: China Science Press, 2018-01-01.

[52] Xie J M, Yin W Y. The primary analysis on the affect of sunshine duration on tobacco leaves' quality in the mid-low elevation of Honghe district [J]. Journal of Guizhou Meteorology, 2006, 30 (1): 34-36.

[53] Dong X Q, Xu H, Yang X P, Yang Y, Zhou G C. GIS-based study of a method of flue-cured tobacco planting suitability regionalization in Yunnan province [J]. Chinese Journal of Agrometeorology, 2005, 26 (1): 16-19.

[54] Guo Y C, Zhang Y D, Li F L, Chen Y, He C G, Hu Z M. Comparison of Growth Period, Yield and Value in Flue-cured Tobacco Pattern of Transplanting Young Seedlings under Film to Conventional Transplanting above Film and Its Correlation with Meteorological Factors [J]. Journal of Yunnan Agricultural University (Natural Science), 2017, 32 (2): 246-256. 